\title{
BIOSORBEN KITOSAN CANGKANG KEONG SAWAH TERHADAP PENYERAPAN ZAT WARNA METHYLENE BLUE
}

\section{[Absorption of Methylene Blue Dyes Using Chitosan from Rice Conch Shell as A Biosorbent]}

\author{
$\operatorname{Iget}{ }^{{ }^{\star}}$, Nurhaeni ${ }^{1}$, Ruslan $^{1}$, Dwi Juli Puspitasari ${ }^{1}$ \\ 1) Jurusan Kimia, Fakultas MIPA, Universitas Tadulako, Palu \\ Jl. Soekarno Hatta Km.9, Kampus Bumi Tadulako Tondo Palu, Telp. 0451- 422611 \\ *)Coresponding author: igetrais06@gmail.com (082347371780)
}

Diterima 29 Mei 2019, Disetujui 29 Juli 2019

\begin{abstract}
Biosorbent studies on methylene blue absorption using chitosan from rice conch shell have been carried out. This research was carried out with variations in contact time of $1,2,3,4,5$, and 6 hours with the aim to determine the contact time required to adsorb Methylene Blue dyes by chitosan from rice conch shell with the highest adsorption capacity. The results showed that the contact time required to adsorb Methylene Blue dye by a chitosan from rice conch shell was 6 hours with the highest adsorption capacity of $85.05 \%$.
\end{abstract}

Keywords: Chitosan, adsorption, Methylene Blue

\begin{abstract}
ABSTRAK
Telah dilakukan penelitian biosorben kitosan cangkang keong sawah terhadap penyerapan zat warna methylene blue. Penelitian ini dilakukan dengan variasi waktu kontak 1, 2, 3, 4, 5, dan 6 jam dengan tujuan untuk mengetahui waktu kontak yang diperlukan dalam mengadsorbsi zat warna Methylene Blue oleh kitosan cangkang keong sawah dengan kapasitas adsorbsi tertinggi. Hasil penelitian menunjukkan bahwa waktu kontak yang diperlukan dalam mengadsorbsi zat warna Methylene Blue oleh kitosan cangkang keong sawah ialah 6 jam dengan kapasitas adsorbsi tertinggi $85,05 \%$.
\end{abstract}

Katakunci : Kitosan, penyerapan, Methylene Blue. 


\section{LATAR BELAKANG}

Zat warna Methylene Blue digunakan secara luas pada industri tekstil dan menjadi perhatian besar dalam proses pengolahan limbah karena warnanya yang sulit diuraikan. Senyawa ini bersifat toksik, menyebabkan mutasi genetik dan berpengaruh pada reproduksi. Senyawa ini memiliki rumus molekul $\mathrm{C}_{16} \mathrm{H}_{18} \mathrm{CIN}_{3} \mathrm{~S} .3 \mathrm{H}_{2} \mathrm{O}$ dengan bobot molekul $373,91 \mathrm{gram} / \mathrm{mol}$. berwarna hijau tua, tidak berbau dan stabil dalam udara serta mudah larut dalam air (larutannya berwarna biru tua), klorofrom dan alcohol. Methylene Blue merupakan salah satu zat warna thiazine yang sering digunakan, karena harganya ekonomis dan mudah diperoleh. Zat warna Methylene Blue merupakan zat warna dasar yang penting dalam proses pewarnaan kulit, kain mori, kain katun dan tannin. Penggunaan Methylene Blue dapat menimbulkan beberapa efek, seperti iritasi saluran pencernaan jika tertelan, menimbulkan sianosis jika terhirup dan iritasi pada kulit jika tersentuh oleh kulit. Dalam pewarnaan, senyawa Methylene Blue hanya digunakan sekitar $5 \%$ sedangkan sisanya $95 \%$ akan dibuang sebagai limbah (Hawley, 1981)

Salah satu cara yang dilakukan untuk mengolah limbah yaitu dengan cara adsorbs. Salah satu adsorben yang dapat digunakan untuk menyerap zat warna adalah kitosan.Kitosan biasa diperoleh melalui deasetilasi kitin.Salah satu sumber kitin adalah dari cangkang keong sawah.
Keong sawah merupakan hewan lunak (molllusca) dari kelas gastropoda. Keong sawah menurut jenisnya dapat dibedaan menjadi empat yaitu Achatina variegate, Achatina fulica, Helix pomatia dan Helix aspersa sedangkan di Indonesia hanya terdapat jenis Achanita variegate dan Achatina fulica. Keong sawah di Indonesia dibudidayakan sebagai sumber protein dan menjadi komoditas ekspor.

Keong sawah merupakan hewan mollusca dari kelas gastrophoda. Keong jenis ini banyak ditemukan di sawah yang pada umumnya menjadi hama karena memakan batang padi yang baru di tanam sehingga mengganggu pertumbuhan padi. Selain menjadi hama, keong sawah juga belum dimanfaatkan secara maksimal. Pemanfaatan keong terbatas pada konsumsi daging keong oleh sebagian masyarakat yang menyebabkan cangkangnya sangat melimpah dan mudah ditemukan.Dalam cangkang keong sawah terdapat kandungan kitin yang menjadi bahan utama pembuatan kitosan.Penelitian yang dilakukan oleh (Hendrawan dan Rachmawani, 2011), kitosan yang diperoleh dari 385 gram cangkang keong bakau (Telescopium sp) adalah sebanyak 33 gram atau sekitar 8.5\%. Stephen et al. (2006) menyebutkan bahwa cangkang gastropoda memiliki kandungan kitin mencapai $20 \%$.

Telah dilakukan penelitian oleh Poerwati (2011). Terhadap cangkang bekicot (Achatina fulica). Dari hasil pelitian cangkang bekicot mampu menghilangkan 
warna dari limbah cair hasil pewarnaan industri tekstil dengan persentase sebesar $88,05 \%$ dengan pengadukan selama 72 jam.

Pada penelitian lain yang dilakukan oleh Matheis et al. (2012), kitosan dari limbah cangkang kepiting rajungan (Partunus sanginolentus L.) dapat dimanfaatkan sebagai absorben biru metilena dengan persen adsorbsi rata-rata $51,95 \%$.

Pembuatan dan pemanfaatan kitosan sulfat dari cangkang bekicot (Achatina fullica) sebagai adsorben zat warna Remazol Yellow FG6. Kitosan sulfat dapat dibuat dari kitosan hasil deasetilasi kitin cangkang bekicot dengan rendemen 5,46 \%. Karakterisasi kitosan sulfat meliputi kadar air 1,50\%, kadar abu $93,51 \%$ dan sulfat yang menempel 6,46 $\mathrm{mg} / \mathrm{g}$. Kitosan sulfat dengan kadar abu 93,51\% dapat menyerap larutan Remazol Yellow FG 6 pada kondisi optimum $\mathrm{pH} 4$, konsentrasi 20 ppm dan waktu kontak 15 menit dengan daya serap 0,64 mg/g. Adsorpsi kitosan sulfat terhadap limbah zat warna menunjukkan $84,5 \%$ zat warna terserap dengan daya serap 0,41 $\mathrm{mg} / \mathrm{g}$ dan desorpsi sebesar 73,2\% (Anggraini Puspitasari, 2007)

Pemanfaatan cangkang pensi (Corbicula moltkiana) sebagai bahan penyerap zat warna Rhodamin $B$ dalam larutan. Dari hasil penelitian cangkang pensi yang telah diaktivasi dengan $\mathrm{HNO}_{3}$ 0,01m dapat digunakan untuk menyerap zat warna Rhodamin $B$ pada kondisi optimum penyerapan $\mathrm{pH} 2$, konsentrasi 150 mg/l. Waktu kontak 105 menit, massa biosorben 0,1 gram, ukuran partikel $32 \mu \mathrm{m}$ dan suhu pemanasan biosorben $75^{\circ} \mathrm{C}$ dengan kapasitas biosorpsi maksimum sebesar 0,9958 mg/g (Mutia, 2017). Berdasarkan uraian di atas perlu dilakukan penelitian tentang Biosorben Kitosan Cangkang Keong Sawah Terhadap Penyerapan Zat Warna Methylene Blue.

Dari latar belakang diatas maka perlunya dilakukan penelitian penyerapan zat warna metilen blue oleh kitosan yang terbuat dari cangkang keong sawah dalam rangka pengembangan pengolahan limbah menggunakan kitosan.

\section{METODE PENELITIAN}

\section{Bahan dan Peralatan}

Bahan-bahan yang digunakan adalah $\mathrm{NaOH}$ (Merck), $\mathrm{HCl}$ (Merc), Aseton (Merc), $\mathrm{NaOCl}$ (Merc), Metilen blue (Merc), dan cangkang keong sawah.

Alat-alat yang digunakan adalah beberapa perlatan kaca, neraca analitik, oven, termometer, hotplate, penyaring Buchhner, blender, tapisan 40 mesh, spektrofotometer FTIR Perkins-Elmer 1600 dan spektrofotometer UV-Vis.

\section{Prosedur Penelitian}

\section{Preparasi Sampel dan pembuatan kitosan (Agustina, 2013)}

Cangkang keong sawah yang telah dicuci dan dikeringkan didalam oven pada suhu $80^{\circ} \mathrm{C}$ selama 24 jam lalu dihaluskan untuk mendaptakan partikel berukuran 40 
mesh. Isolasi kitosan dari cangkang keong sawah. Prosedur ini terdiri atas 4 tahap yaitu, deprotainase, demineralisasi, depigmentasi, dan deasetilasi. Pada tahap yang pertama, $100 \mathrm{~g}$ cangkang keong sawah ditambahkan larutan $\mathrm{NaOH} 3,5 \%$ dengan nisbah 1:10 (w/v) dan dipanaskan pada suhu $65^{\circ} \mathrm{C}$ selama 2 jam. Selanjutnya campuran didingankan, disaring, dan residu dikeringkan. Tahap yang berikut dimulai dengan residu ditambahkan dengan larutan $\mathrm{HCl} 1,0 \mathrm{~N}$ dengan nisbah 1:15 (w/v) dan dibiarkan selama 30 menit pada suhu kamar. Setelah itu campuran disaring, dicuci, dan dikeringkan pada suhu $60^{\circ} \mathrm{C}$ selama 4 jam. Tahap selanjutnya adalah depigmentasi, residu ditambahkan aseton secukupnya dan hasilnya diputihkan dengan menggunakan $\mathrm{NaOCl}$ 0,315\% dengan nisbah 1:10 (w/v), dibiarkan selama 30 menit pada suhu kamar, dicuci, dan dikeringkan. Selanjutnya melalui tahap deasetilasi, residu ditambahkan dengan larutan $\mathrm{NaOH} 50 \%$ pada suhu 100-150oC selama 6 jam, didinginkan, disaring, dicuci, dikeringkan dan dianalisis dengan menggunakan spektofotometer FTIR.

\section{Pembuatan larutan Methylene Blue dan Penentuan Panjang Gelombang Maksimum (Widihati et al., 2011)}

Larutan induk metilen blue 1000 ppm dibuat dengan menimbang secara teliti serbuk Methylene Blue sebanyak 0,5 g kemudian dilarutkan dalam gelas beker lalu dipindahkan secara kuantitatif ke dalam labu ukur $500 \mathrm{~mL}$ dan diencerkan menggunakan akuades sampai tanda batas sehingga diperoleh larutan standar Methylene Blue 1000 ppm. Kemudian larutan eksperimen disiapkan dari $2 \mathrm{ml}$ larutan baku yang diencerkan hingga volume $100 \mathrm{ml}$ untuk mendapatkan konsentrasi 20 ppm. Pengukuran panjang gelombang maksimum dilakukan pada panjang gelombang 400-700 nm dengan spektrofotometer UV-Vis.

\section{Penentuan Waktu Kontak Optimum (Widihati et al., 2011)}

Sebanyak 0,25 gram dalam $25 \mathrm{~mL}$ larutan eksperimen, diatur pada $\mathrm{pH} 7$ dengan penambahan bufferphosphat, dikocok dengan variasi waktu kontak 1, 2, 3, 4, 5 dan 6 jam. .Setelah pengocokan selesai larutan disaring dan filtrat diukur absorbansinya pada panjang gelombang maksimum.

\section{HASIL DAN PEMBAHASAN}

\section{Isolat Kitosan dari Cangkang Keong Sawah}

Serbuk keong sawah melalui tahapan deproteinase yang bertujuan untuk menghilangkan protein yang terkandung dalam keong sawah menggunakan $\mathrm{NaOH} \quad 3,05 \%$ dengan nisbah 1:10 (w/v) pada suhu $65^{\circ} \mathrm{C}$ selama 2 jam pada proses deproteinase ini, protein diubah menjadi garam natrium proteinal yang larut air. Pada tahap berikutnya serbuk keong sawah yang telah melalui tahap deproteinase dilakukan tahap demineralisasi 
menggunkan $\mathrm{HCl} 1 \%$ dengan nisbah 1 : $10(\mathrm{w} / \mathrm{v})$ dan dibiarkan selama 30 menit reaksi yang terjadi dalam kalsium menurut salami (1998). Timbulnya gelembung gas $\mathrm{CO}_{2}$ merupakan indicator adanya reaksi $\mathrm{HCl}$ dengan garam mineral yang terdapat dalam cangkang keong sawah (Pilla ampullacea) menurut Arif et al. (2013). Bahwa kandungan mineral yang terdapat dalam hewan hewan moluska yaitu $\mathrm{CaCO}_{3}$ dan $\mathrm{Ca}_{3}\left(\mathrm{PO}_{4}\right)_{2}$. Selanjutnya proses depigmenasi untuk menghilangkan pengotor dan zat warna yang mungkin terdapat pada kitin dimana residu hasil demineralisasi ditambahkan $\mathrm{NaOCl}$ 0,315\% dengan nisbah $1: 10$ dibiarkan selama 30 menit pada suhu ruang, dicuci dan dikeringkan. Menurut Hamsina, dkk (2002) penggunaan $\mathrm{NaOCl}$ bertujuan untuk menghilangkan pigmen (zatwarna) yang terkandung dalam cangkang keong sawah yang merupakan senyawa lipo protein, dimana gugus lipidanya adalah senyawa karotenoid. Sehingga kitin yang diperoleh akan berwarna putih bersih dari warna semulanya Tahap terakhir adalah isolasi kitosan dengan tahap deasetilasi gugus asetil yang terikat pada $\mathrm{N}$-amida menggunakan $\mathrm{NaOH} 50 \%$ pada suhu 100$150^{\circ} \mathrm{C}$ selama 6 jam. Deasetilasi merupakan proses pengubahan gugus asetil $\left(-\mathrm{CH}_{3} \mathrm{COO}^{-}\right)$Pada kitin menjadi gugus amina pada kitosan dengan penambahan $\mathrm{NaOH}$ kosentrasi tinggi. Reaksi deasetilasi kitin pada dasarnya adalah suatu reaksi hidrolisis amida dari alfa 1,4-2-aset amida-2-deoksi-D-glukosa.
Proses pelepasan gugus asetil dari gugus asetamida kitin berhubungan dengan konsentrasi ion $\mathrm{OH}$ pada larutan. Konsentrasi $\mathrm{OH}$ akan lebih besar pada larutan basa kuat. Semakin kuat suatu basa semakin besar konsentrasi $\mathrm{OH}^{-}$ dalam larutannya (Ashar dkk, 2010).

\section{Gugus fungsi dan derajat deasetilasi kitosan}

Proses Analisis gugus fungsi berfungsi untuk mengetahui karakteristik pita serapan kitosan dengan menggunakan spektrofotometri IR. Analisis spectrum dipusatkan pada penentuan adatidaknya sejumlah gugus fungsional. Sastrohamidjojo (1992) dalam Rizqiyah (2007), gugus fungsional pada kitin dan kitosan yaitu gugus karbonil, gugus amida, gugus hidroksi, aldehida, dan amina primer. Derajat deasetilasi menunjukkan berkurangnya gugus asetil dari kitin menjadi gugus amina pada kitosan yang ditentukan dari hasil spektrum FTIR. Banyaknya gugus asset amida yang hilang dari atom $\mathrm{C}_{2}$ dari monomer kitin akan menunjukan tingginya nilai derajat deasetilasi dimana mekanisme reaksinya diawali dengan masuknya gugus hidroksil $\left(\mathrm{OH}^{-}\right)$dari $\mathrm{NaOH}$ ke atom C karbonil. Hal ini disebabkan karena gugus hidroksil memiliki pasangan elektron bebas yang bersifat nukleofilik. Masuknya gugus hidroksil terjadi pada atom C karbonil disebabkan karena adanya efek induksi sehingga elektron pada atom $\mathrm{C}$ karbonil 
mengarah ke atom $\mathrm{O}$ yang menyebabkan atom C karbonil sangat elektropositif. Hasil yang ditimbulkan akibat masuknya gugus hidroksil ke atom $\mathrm{C}$ karbonil menyebabkan putusnya ikatan $\pi$ pada $\mathrm{C}=\mathrm{O}$ karbonil. Atom $\mathrm{O}$ pada hidroksil $(\mathrm{OH})$ mampu menarik elektron pada $\mathrm{H}$ sehingga menyebabkan terbentuknya proton. Atom
$\mathrm{N}$ yang memiliki satu pasang elektron bebas dapat menarik proton sehingga membentuk ion ammonium. Untuk menstabilkan atom $\mathrm{N}$ maka terjadi pemutusan ikatan $\mathrm{N}-\mathrm{C}$ yang disertai pembentukan ikatan $\mathrm{C}=\mathrm{O}$ sehingga terbentuk kitosan.

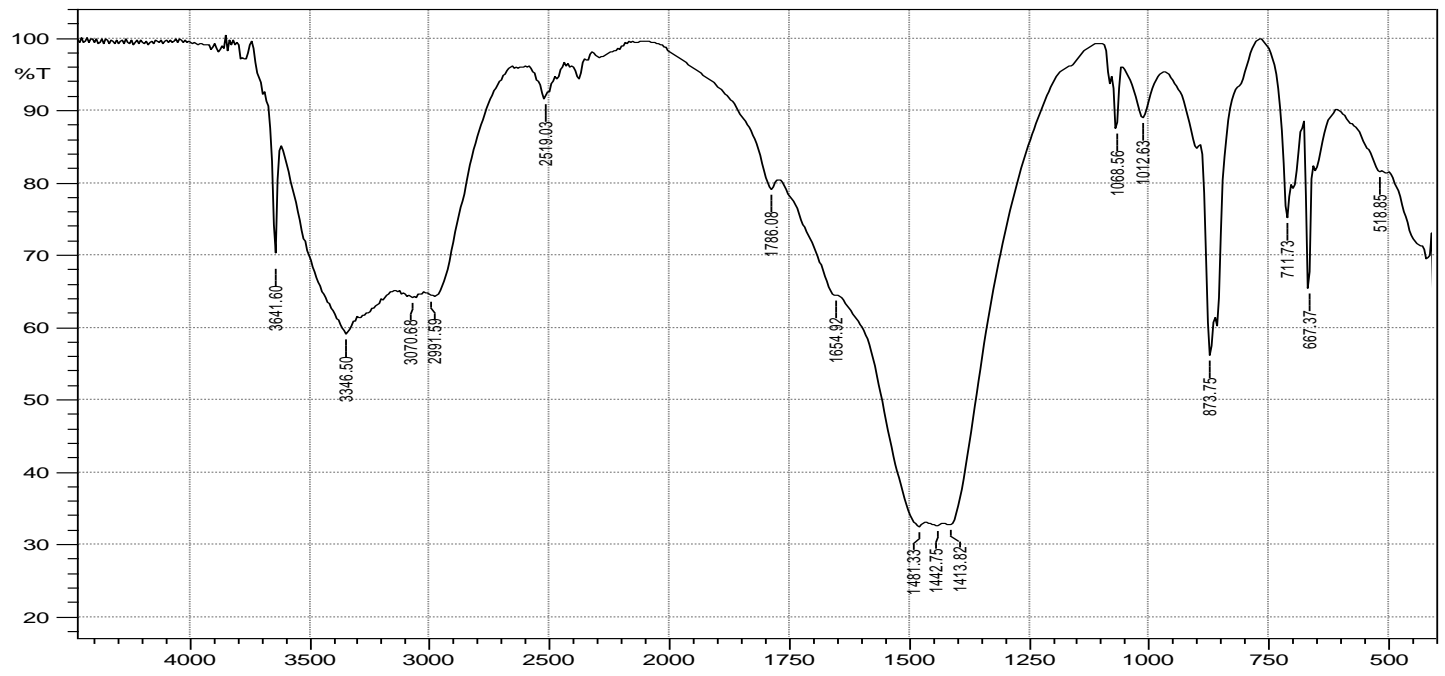

Gambar 1 Spektrum FTIR kitosan cangkang keong sawah

Spektrum kitosan cangkang keong sawah menunjukkan adanya pita serapan pada bilangan gelombang $3346.50 \mathrm{~cm}^{-1}$ yang menunjukkan gugus fungsi $\mathrm{OH}$ ulur dan NH ulur (Gambar 1). Pita serapan pada bilangan gelombang $2991.59 \mathrm{~cm}^{1}$ menunjukkan gugus fungsi $\mathrm{CH}_{2}$ ulur, pita serapan pada bilangan gelombang $1654.92 \mathrm{~cm}^{-1}$ menunjukkan adanya gugus $\mathrm{C}=\mathrm{O}$ amida, pita serapan pada bilangan gelombang $1012.63 \mathrm{~cm}^{-1}$ menunjukkan adanya gugus fungsi C-O-C. Penentuan derajat deasetilasi dilakukan untuk mengetahui terbentuknya kitosan dari kitin. Penentuan derajat deasetilasi kitosan dihitung dengan base line seperti yang diusulkan oleh Baxter (Wiyarsi et al., 2009).

Penggunaan base line dari spektrum FTIR dilakukan dengan cara membandingkan absorbs pada bilangan gelombang -NHCO $\left(1650 \mathrm{~cm}^{-1}-1500 \mathrm{~cm}^{-}\right.$ $\left.{ }^{1}\right)$ dengan absorbansi bilangan gelombang gugus amina primer $-\mathrm{NH}_{2}\left(3500 \mathrm{~cm}^{-1}-\right.$ $3200 \mathrm{~cm}^{-1}$ ) (Basttaman, 1989 dalam Rezqiyah, 2007), dari perbanding tersebut diperoleh nilai derajat deasetilasi (DD) kitosan cangkang keong sawah (Pillaampullace) yaitu $83,23 \%$. Menurut Hayes dalam Fitri (2005) dan Rezqiyah (2007), jika derajat deasetilasi $<60 \%$ disebut kitin, dan apabila lebih dari $>60 \%$ disebut kitosan. Berdasarkan standar 
Proton Laboratorium, kitosan keong sawah yang diperoleh dapat di pasarkan, karena standar derajat deasetilasi kitosan pasaran harus $\geq 70 \%$. Kitosan dengan derajat deasetilasi > $60 \%$ telah memenuhi standar untuk digunakan sebagai adsorben.

\section{Pengaruh waktu kontak terhadap penyerapan zat warna metilen blue.}

Penentuan konsentrasi metilen blue dilakukan dengan menggunakan kurva standar metilen blue (Gambar 2). Nilai konsentrasi yang tersisa akibat penyerapan kitosan cangkang keong sawah diperoleh dari persamaan regresi linear dengan $(\mathrm{x})$ sebagai konsentrasi larutan standar metilen biru dan (y) adalah absorbansi larutan standar.

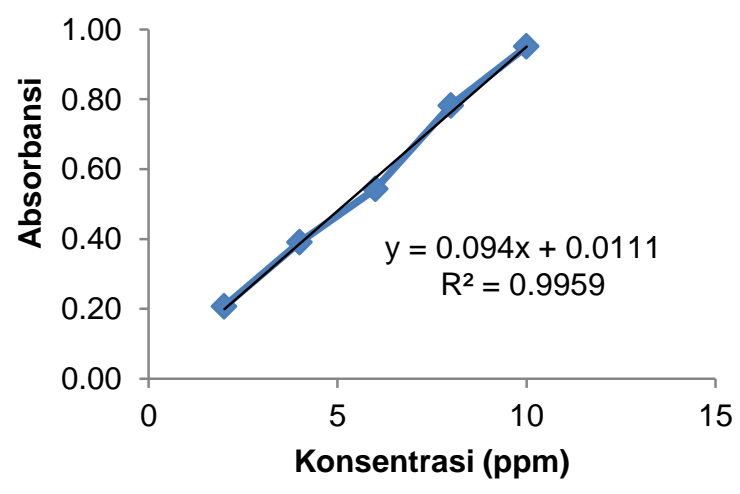

Gambar 2 Kurva hubungan konsentrasi dan absorbansi larutan standar.

Persamaan linear larutan standar metilen blue adalah $y=0.094 x+0.0111$ dengan konsentrasi (ppm) sebagai sumbu $x$ dan nilai absorbansi sebagai sumbu y (Gambar 2). Data adsorpsi penyerapan metilen biru pada waktu kontak optimum dengan penggunaan sebanyak 0,25 gram abusekam dalam $25 \mathrm{~mL}$ larutan eksperimen 20 ppm, dilakukan proses penyerapan pada $\mathrm{pH} 7$ dapat dilihat pada Gambar 3.

Hasil penelitian menunjukkan bahwa waktu kontak optimum yang diperlukan untuk penyerapan metilen biru oleh kitosan cangkang keong sawah adalah 6 jam dimana \% kapasitas penyerapan metilen biru oleh kitosan mencapai 85,05 $\%$. Hal ini diperkuat dengan analisis uji menggunakan SPSS metode One-Way ANOVA menunjukkan bahwa nilai signifikan dari waktu kontak terhadap kapasitas adsorbs sebesar 0,000< $\alpha$ $(0,05)$ sehingga dilanjutkan ke uji lanjutan Duncan. Hasil uji Duncan menunjukkan waktu kontak 1 jam dan 2 jam berbeda tidak nyata dan waktu kontak 6 jam, 5 jam, 4 jam, dan 3 jam berbed anyata. Sehingga kapasitas adsorbs tertinggi terdapat pada waktu kontak 6 jam sebesar 17,005.

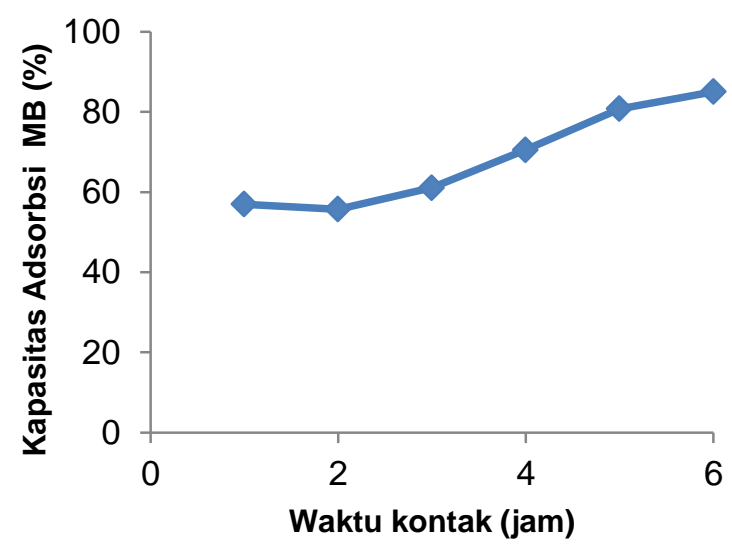

Gambar 3 Pengaruh waktu kontak terhadap \% kapasitas penyerapan metilen biru oleh kitosan cangkang keong sawah

Berdasarkan penelitian yang dilakukan oleh zainal dkk. Terhadap adsorpsi zat warna Direct black 38 menggunakan kitosan berbasis limbah 
udang delta Mahakam menunjukan bahwa waktu kontak maksimum yang diperoleh 360 menit (6 Jam).

Pada penelitian lain yang dilakukan oleh Mardiyah et al. (2016). Terhadap adsorpsi Rhodamin B dengan adsorben kitosan kitosan serbuk dan Beads kitosan dapat mengadsorpsi Rhodamin B secara optimum masing-masing pada $\mathrm{pH} 4$ dan 3 dengan waktu kontak 120 menit dan 180 menit dengan panjang gelombang maksimum 554,2 $\mathrm{nm}$.

\section{KESIMPULAN}

Waktu kontak yang diperlukan dalam mengadsorbsi zat warna Methylene Blue oleh kitosan cangkang keong sawah ialah 6 jam dengan kapasitas adsorbsi tertinggi $85,05 \%$. Perlu dilakukan penelitian lebih lanjut yaitu pengaruh $\mathrm{pH}$ terhadap daya adsorpsi zat warna methylene blue oleh kitosan yang terbuat dari cangkang keong sawah.

\section{DAFTAR PUSTAKA}

Arif A.R., Ischaidar., Natsir Hasnah., Dali Seniwati. 2013. Isolasi Kitin Dari Limbah Udang Putih. Proseding Seminar Nasional Kimia 2013. Makassar: Universitas Hasanuddin.

Widihati, I A G., Diantariani N.P., Yuliana Nikmah, Y F. 2011. Fotodegradasi Metilen Biru dengan Sinar Uv dan Katalis $\mathrm{Al}_{2} \mathrm{O}_{3}$. Jurnal Kimia, 5(1).

Fitri, K. 2005. Kajian Adsorpsi dan Desorpsi $\mathrm{Ag}\left(\mathrm{S}_{2} \mathrm{O}_{3}\right)_{2}{ }^{3-}$ dalam Limbah Fotografi pada dan dari Adsorben Kitin dan Asam Humat Terimobilisasi pada Kitin. Tesis. Yogyakarta: Universitas Gadjah Mada.
Hawley, 1981. Condensed Chemical Dictionary. Eleventh ed, New York: Van Nortrand Reinhold.

Hendrawan dan Rachmawani, D. 2011. Studi Kandungan Kitosan Pada Keong Bakau (Telescopium sp) di Kawasan Konservasi Mangrove Kelurahan Pamusian Kota Tarakan. Jurnal Harpodon Borneo, 4(2).

Mardiyah Kurniasih, anung Riapanitra, Anas Rohadi, 2016. Adsorpsi Rhodamin B dengan Adsorben Kitosan Serbuk dan Beads Kitosan. Sains \& Matematika, 2(2).

Matheis F. J. D. P. Tanasale, Amos Killay, dan Marsela S. Laratmase.2011, Kitosandari Limbah Kulit Kepiting Rajungan (Portunus sanginolentus L) sebagaiAdsorben Zat Warna Biru Metilena. Jurnal Natur Indonesia, 14 (2): 165-171.

Mutia, K. A. 2017. Pemanfaatan Cangkang Pensi (Corbicula Moltkiana) sebagai Bahan Penyerap Zat Warna Rhodamin B dalam Larutan. Disertasi. Padang: Universitas Andalas.

Poerwati, S. 2011. Pemanfaatan Cangkang Bekicot dalam Pengolahan Limbah Cair Hasil Pewarnaan Industri Tekstil. Jurnal Penelitian Kesehatan Suara Forikes, 2 (2): 1-6.

Rizqiyah. 2007. Isolasi Dan Identifikasi Kitin, Kitosan Dari Cangkang Hewan Mimi (Horseshoe Crab) Menggunakan Spektrofotometri Infra Merah. ALCHEMY, 2(1).

Stephen, A M., Philips, G O., Williams, P A. 2006. Food Polysaccharides and Their Application. CRC Press : Florida, USA. 